\title{
CHRZEŚCIJANIN BEZ BOGA. TEOLOGIA POLITYCZNA PIERRE’A BOURDIEU
}

Michał Łuczewski

Uniwersytet Warszawski

Były teolog, który został socjologiem, może przy okazji badania środowiska teologów ulec regresowi i zacząć mówić jako teolog albo, co gorsza, posłużyć się socjologia, aby wyrównać swe rachunki teologa.

Pierre Bourdieu

Tym, co daje wyzwolenie, jest wiedza co do tego, kim byliśmy, czym się staliśmy; gdzie byliśmy i gdzie zostaliśmy wrzuceni; dokąd spieszymy, od czego jesteśmy wybawieni; czym są narodziny, a czym odrodzenie.

Szkoła Walentyna

Prawie wszystkie istotne pojęcia z zakresu nauki Pierre'a Bourdieu to zsekularyzowane pojęcia teologiczne: symbol, wiara, dar, paradoks, wcielenie, scholastyka, uświęcenie, ortodoksja, kapłan, heretyk, konwersja, teodycea ${ }^{1}$. Trudno znaleźć stronę w pismach francuskiego socjologa, na której nie pojawiałyby się religijne odwołania i metafory: ordynacja, transsubstancjacja, cud, łaska, medytacja, mistyka, liturgia, asceza, potępienie, uczona niewiedza, efekt zmartwychwstania itp., itd. Choć Bourdieu nie poświęcił religii wielu studiów, nie sposób wyobrazić sobie bez niej całego gmachu jego teorii (Dianteill 2003, Flanagan 2007: 24-26, Verter 2003: 150, Warczok 2010: 154). Podstawowe dla jego systemu pojęcia „habitus” i „pole” są wynikiem namysłu nad problemami w analizie religii u Webera i Panofskiego (zob. także Dianteill 2003: 529-530, Bourdieu 2015; zob. także Bourdieu 2006: 252). Przez jego prace przebija fascynacja katolicyzmem, a zwłaszcza jego średniowiecznymi formami. Kieran Flanagan (2007: 28-29) mówi nawet o „katolicyzmie Bourdieu”. Jest to jednak katolicyzm specyficzny (podobnie jak specyficzny był katolicyzm Comte’a) ${ }^{2}$, albowiem

\footnotetext{
1 „Prawie”, gdyż teoria Bourdieu korzystała także z nieteologicznych pojęć i metafor, takich jak habitus, illusio, przemoc, reprodukcja, kapitał, dominacja i doksa, które pochodziły z innych dziedzin. 2 Jest to kolejny przykład na to, że we Francji nawet sprzeciw wobec katolicyzmu niesie za sobą piętno katolicyzmu (zob. także Peyrefitte 1981).
} 
wykorzystuje on katolickie pojęcia przeciwko katolickiej praktyce, a religijne metafory - przeciwko religijnym przekonaniom. Służą mu do denuncjacji praktyk dyskursywnych, zakrywających stosunki dominacji, których - według Bourdieu - teologia jest modelowym przykładem. W charakterystycznym dla siebie geście we Wstepie do Medytacji pascalianskich (Bourdieu 2006: 10) przy pomocy religijnego języka („W dziedzinie myślenia nie ma [...] niepokalanego poczęcia, ale nie ma też grzechu pierworodnego") odrzuca „resztki religijnego moralizmu”. Paradoksalnie jednak poprzez konsekwentny sprzeciw wobec religii socjologia Bourdieu sama staje się religijna. Im bardziej Bourdieu próbuje uwolnić się od teologii, tym bardziej jej ulega. Następuje tutaj szczególne podwójne wiązanie (double bind).

\section{/// Jedna kryptoteologia}

Bourdieu przenosi pojęcia $z$ teologii do nauki o państwie i społeczeństwie - w ten sposób na przykład wszechmocny Bóg staje się wszechmocnym prawodawcą i wszechmocnym obserwatorem. Podobnie jak przed nim Louis de Bonald, Joseph de Maistre czy Auguste Comte Bourdieu przeprowadza przejrzystą, systematyczną analogię pomiędzy teologią a polityką:

Rytuały instytucjonalne dają wyolbrzymiony, bardzo wyraźny obraz skutku oddziaływania instytucji, arbitralnego bytu, który ma władzę odrywania od arbitralności, przyznawania jednej spośród racji bytu, niczym zapewnienia, że przypadkowa, podatna na choroby, kalectwo i śmierć istota jest, podobnie jak porządek społeczny, godna transcendentnej i nieśmiertelnej godności, jaka została jej przyznana. Akty nominacji zaś, począwszy od tych najbardziej banalnych ze zwykłej biurokracji, takich jak przyznanie dowodu osobistego lub zaświadczenia o chorobie czy inwalidztwie, aż do najbardziej uroczystych, które uświęcaja godnych, prowadzą poprzez pewien rodzaj regresji w nieskończoność, aż do tej realizacji Boga na ziemi, jaką jest Państwo. Zapewnia ono w ostateczności nieskończoną liczbę aktów władzy, które z upoważnienia poświadczają prawomocną ważność świadectwa istnienia (chorego, inwalidy, docenta, proboszcza). Socjologia staje się w ten sposób czymś w rodzaju teologii ostatniej instancji. Państwo, jak sąd Kafki, dysponuje absolutną władzą wiarygodności i twórczej percepcji, które powołuje do istnienia za pomocą mianowania i odróżniania, jest, jak mówi Kant, podobne do boskiego intuitus originarius. Widzimy, 
że kiedy Durkheim mówił, tak jak mógłby powiedzieć też Kafka, że „społeczeństwo to Bóg”, nie był tak naiwny, jak chce się, abyśmy sądzili (Bourdieu 2006: 349-350).

W oryginale brzmi to jeszcze mocniej, bo tam zdanie, które wieńczy Medytacje pascaliańskie, brzmi: „la société, c'est Dieu”. Bourdieu oddaje ostatnie słowo „Bogu”. Nasycenie religijnym językiem jest tutaj niezwykle silne, a zdanie „socjologia staje się czymś w rodzaju teologii ostatniej instancji” brzmi szczególnie mocno. Co ma na myśli Bourdieu? W zgodzie z regułami francuskiej nauki nikt, kto chce zdominować jej pole (a tego właśnie pragnął Bourdieu), nie może wypowiadać się w sposób zbyt jasny (zob. także Lamont 1987). Bourdieu uprawia tutaj skomplikowaną intertekstualną grę, nie cytując dzieł, na które się powołuje. Pozostaje on wierny swemu przekonaniu, że socjologia jest nauką ezoteryczną, która jedynie z pozoru wydaje się czymś prostym i przystępnym (Bourdieu 1990: 53).

W powyższym fragmencie Bourdieu parafrazuje fragmenty swojego wcześniejszego tekstu Duchy państwa. Geneza i struktura pola biurokratycznego, który stanowił podsumowanie trzyletniego cyklu wykładów w Collège de France (Bourdieu 2014). „Kto potwierdza ważność certyfikatu? - pytał retorycznie (Bourdieu 2009: 92). - Ten, kto podpisał tytuł dający licencję do certyfikowania. Lecz kto go z kolei certyfikował? Tutaj wciaga regresja w nieskończoność, którą «trzeba zatrzymać», na przykład, na sposób teologów, postanawiając nazwać państwem ostatnie (lub pierwsze) ogniwo długiego łańcucha oficjalnych aktów konsekracji”. Przypomina to sposób rozumowania św. Tomasza, który dowodził istnienia Boga, wykazując, że każdy skutek musi mieć swoja przyczynę i w związku z tym musi istnieć przyczyna najwyższa. Owa najwyższa przyczyna jest jednocześnie najpotężniejszym źródłem prawomocności i życia. W tym duchu Bourdieu wyjaśniał, że państwowe procedury „maja zdolność tworzenia (lub ustanawiania) przez magię oficjalnej nominacji, w publicznych deklaracjach społecznie gwarantowanych społecznych tożsamości [...] czy też prawomocnych związków i grup [...]”. W ten sposób państwo sprawuje „władzę twórczą, niemal boską" (Bourdieu 2009: 93).

Najważniejszym tekstem teologicznym Bourdieu jest króciutki esej Ostatnia instancja (1984), który przygotował ku czci Franza Kafki. Właśnie do niego odwołują się jego późne prace, w których teologia staje się coraz ważniejszym punktem odniesienia: Medytacje pascaliańskie, Męska dominacja, Zaproszenie do socjologii reflekssynej i Science de la science et réflexivité. Otóż w Ostatniej instancji przeprowadził po raz pierwszy dowód, ,że wizja socjologiczna 
i teologiczna łączą się mimo pozornego przeciwieństwa" (zob. także Bourdieu 2009: 92). „Ostatnia instancja” to najwyższy, niewidzialny trybunał, który skazał Józefa K. na areszt. Socjologia jest zmuszona poszukiwać „niewidzialnego trybunału” i „ostatniej instancji”, gdyż każda próba odpowiedzi na pytanie o istotę tożsamości społecznej kieruje nas ku „instancjom konsekracji”, które poprzez „werdykty” i „magię prawdy” powołuja do istnienia każdą społeczną tożsamość. Nauka rozpoczyna od instancji najniższych (od drugiego człowieka, od instytucji edukacyjnych), a kończy na poszukiwaniu ,absolutnego punktu widzenia”, „instancji metafizycznej”, „instancji uprawomocniającej zdolnej do uprawomocnienia instancje uprawomocniające”. „To jedna z przyczyn, dla których socjologia - jeśli nie jesteśmy ostrożni - tak często staje się teologią" (Bourdieu 1984: 270). Socjologia staje się teologią ostatniej instancji, albowiem zajmuje się rzeczą pierwszą i ostatnią: Państwem, które jest „realizacją Boga na ziemi”.

Sięganie do ostatniej instancji wiąże się dla Bourdieu z pewnym niebezpieczeństwem, które polega na tym, że podobnie jak socjolog sztuki religii nie powinien używać języka artystów (czy socjolog, który zajmuje się Bourdieu, powinien używać jego teorii?), tak socjolog państwa nie powinien używać języka państwowego: „myślenie o państwie stwarza ryzyko myślenia państwowego" (Bourdieu 2009: 75). Jest to zagrożenie bardzo poważne, gdyż państwo wytwarza swój własny rozum (raison d'Etat; Bourdieu 2004a) i tworzy na swój własny użytek instytucje edukacyjne (Bourdieu 1996). Socjologowie, którzy „myśla państwowo” zamiast wyjaśniać i opisywać państwo, zaczynaja je legitymizować i nadawać mu rację bytu (raison d'Etat). Nawet ci, którzy z nim walczą, np. reprezentując zdominowane mniejszości, w istocie utwierdzaja jego władzę, domagają się bowiem od niego uznania reprezentowanych tożsamości. Również i dla nich „sąd państwa jest sądem ostatecznym” (Bourdieu 2009: 93). Socjologia nie może dać jednak państwu ostatniego słowa. Państwo nie jest dla socjologii „ostatnią instancją". Ostatnią instancją może być tylko socjologia. Krótko mówiąc: socjologia jest teologia ostatniej instancji, bo to do niej (jak wcześniej do teologii), należy sąd ostateczny.

\section{/// Dwa ciała Bourdieu}

Mimo że Bourdieu odwołuje się w przywoływanym fragmencie do Kanta, Durkheima i Kafki, to w istocie jego głównym źródłem inspiracji jest niewymieniony tu Ernst Kantorowicz. Opis realnych efektów rytuałów, które tak go fascynowały i zbliżały do katolicyzmu, Bourdieu (1993: 
15) odnalazł najpierw w Dwóch ciałach króla, dziele analizującym - jak podsumowywał, używając niemal tych samych słów, co w Medytacjach - „,społecznie uznane wybiegi, do których odwoływano się, aby utwierdzić istnienie władzy królewskiej transcendującej prawdziwe ciało króla, cierpiącego z powodu niedołęstwa, choroby, słabości i śmierci”.

Przywoływany na początku fragment poprzedzony został akapitem, który - ponownie bez odwołania do Kantorowicza - wprost przywołuje ideę dwóch ciał: wiecznego, niewidzialnego, mistycznego ciała społecznego (np. Kościoła, republiki, urzędu, Korony), w którym uczestniczy śmiertelne, widzialne, naturalne ciało człowieka (np. kapłan, obywatel, urzędnik, król). Dzięki temu połączeniu śmierć człowieka nie skutkuje rozwiązaniem funkcji, jaką wypełniał, tak jak śmierć króla nie powoduje śmierci Korony ${ }^{3}$. Bourdieu przywołuje różne figury ciał społecznych, „które nie umierają nigdy": universitas, collegium i societas. Każdemu z nich Kantorowicz (2007: 219-250) poświęcił bardzo wnikliwe passusy. Co więcej, francuski socjolog przywołuje tytuły podrozdziałów Dwóch ciał króla: dignitas non moritur (Bourdieu 2006: 347, Kantorowicz 2007: 304-355) i - tym razem wprost pro Patria mori (Bourdieu 2006: 209, Kantorowicz 2007: 187-218). Wreszcie w jednym miejscu powołuje się przelotnie na Kantorowicza analizy związku władzy królewskiej i prawa (Bourdieu 2006: 150), które można znaleźć w pozostałych rozdziałach Dwóch ciat króla (Kantorowicz 2007: 72-156). W ten sposób przy pomocy dwóch oszczędnych przypisów Bourdieu wykorzystał i wyczerpał całą treść tego dzieła. Jako autor Kantorowicz nie istnieje w wywodach Bourdieu i podobnie jak mistyczne ciało pozostaje niewidzialny, ale Bourdieu niejako w nim partycypuje, produkując jak najbardziej widzialne dzieło ${ }^{4}$.

Paraleli między Bourdieu a Kantorowiczem znajdziemy znacznie więcej i to znacznie głębszych, niż świadczyłyby o tym nieliczne odwołania do Dwóch ciat króla. W swoim projekcie rekonstrukcji genezy pól Bourdieu

\footnotetext{
${ }^{3}$ Cytowany przez Kantorowicza (2007: 5-6) Edmund Plowden, prawnik z czasów Elżbiety I, pisał: „Król ma w sobie dwa Ciała, a mianowicie ciało naturalne (body natural) i Ciało wspólnotowe (body politic). Ciało naturalne [...] jest ciałem śmiertelnym, podlegającym wszystkim niemocom [...], podlegającym niedojrzałości, niepełnoletniości albo przypadłościom wieku starczego oraz podobnym skazom, które przydarzają się ciałom naturalnym innych ludzi. Ale jego Ciało wspólnotowe jest Ciałem, którego nie można zobaczyć czy dotknąć, składającym się z polityki i rządu i przeznaczonym do kierowania ludem i zarządzania dobrem publicznym, i to Ciało jest zupełnie pozbawione niemowlęctwa, wieku starczego i innych naturalnych skaz i niedojrzałości”.

${ }^{4}$ W sprawie specyficznych praktyk cytowania Bourdieu zob. także Wagner 2012. Niewymieniony z nazwiska Kantorowicz jest też ukrytym punktem odniesienia dla Duchów państwa, które zajmują się m.in. misteriami państwa, jego specyficzną liturgią, związkami między prawem kanonicznym a biurokracja, , fikcyjnym ciałem” państwa, procesem, w którym prawnicza fikcja, fictio iuris, staje się rzeczywistością, która ustanawia porządek polityczny (Bourdieu 2009: 75-111).
} 
wpisywał się bowiem w projekt „konstytucyjnej semantyki” Kantorowicza. Ten ostatni w swych kolejnych pracach pokazywał proces uwalniania się od teologii i jednoczesnego uświęcania państwa i ludu, prawa i prawników, sztuki i artystów, uniwersytetu i profesorów (zob. Kantorowicz 2008, Pawlik 2008). Każdemu z tych procesów - genezie i transformacji pola państwowego (Bourdieu 2004c, Bourdieu 2009: 75-111; 2014), prawniczego (Bourdieu 1986), artystycznego (Bourdieu 2001) i naukowego - Bourdieu (1988), poświęcił swoje najbardziej znane prace. Różnica między nimi polega na tym, że o ile Kantorowicz analizował średniowieczną teologię polityczną, jedynie sugerując, że jego rozważania można odnieść do współczesnego mu „mitu państwa”, o tyle Bourdieu uniwersalizuje te analizy i odnosi je do nowoczesnego państwa jako takiego. O ile Kantorowicz docenia niekiedy rolę sakralizacji ojczyzny, prawa, nauki czy sztuki, o tyle Bourdieu zmierza do całkowitej jej dekonstrukcji ${ }^{5}$.

Powinowactwa między Bourdieu a Kantorowiczem są czytelne, ale dotąd nie stały się przedmiotem pogłębionej analizy. Co więcej, jeśli ktoś zestawia ze sobą tych dwóch autorów, to nie tyle po to, by ukazać zapożyczenia francuskiego socjologa, ile zapóźnienie niemieckiego historyka. Bernhard Jussen (2009: 114) na przykład, dokonując globalnej oceny Dwóch ciał króla z perspektywy najnowszej literatury przedmiotu, pisze: „Nie możemy zarzucać Kantorowiczowi tego, że nie odrobił lekcji Bourdieu”. Nie zauważa jednak, że Bourdieu bardzo dobrze odrobił lekcję Kantorowicza. To przeoczenie spowodowane jest przede wszystkim tym, że teoretycy operuja w ramach ,anomicznego podziału pracy” (historycy czytaja Kantorowicza, a socjologowie Bourdieu, ale nikt nie czyta ich naraz), a przede wszystkim - mimo ogłaszanego przełomu postsekularnego (zob. także Hałas 2013) - niedocenianiem wątków teologicznych w teorii społecznej. Dzieło Kantorowicza nie dotyczyło bowiem jedynie figury „dwóch ciał”. W miarę pisania jego zamysł znacznie się rozrastał, aż wreszcie autor zrozumiał, że pisze - jak głosi podtytul - studium ze średniowiecznej teologii politycznej (zob. także Kantorowicz 2007: XXX). Paralele między Kantorowiczem i Bourdieu można zauważyć dopiero wtedy, gdy potraktujemy teologię poważnie i odkryjemy, że w swoich pracach Bourdieu tworzy studium z nowoczesnej teologii politycznej.

\footnotetext{
${ }^{5}$ Ważnym punktem odniesienia w analizie form symbolicznych zarówno dla Kantorowicza, jak i Bourdieu był Ernst Cassirer. W Dwóch ciałach króla Kantorowicz (2007: XXX-XXXI) opowiada się przeciwko różnej maści „teologiom politycznym” i „mitowi państwa”, krytykowanemu przez Cassirera (2006). W słynnym sporze pomiędzy wyrafinowanym Cassirerem a brutalnym Heideggerem, który przywołuje Bourdieu (1991), Kantorowicz staje więc po stronie tego pierwszego.
} 


\section{/// Trzy teologie Schmitta}

Żeby zrozumieć projekt teologii politycznej Bourdieu, musimy odwołać się do Carla Schmitta, który wprowadził to pojęcie do światowej humanistyki. Choć Kantorowicz przywołuje „teologię polityczną” w tytule swego opus magnum, nazwisko jej twórcy, „koronnego jurysty Trzeciej Rzeszy" ani razu się nie pojawia. Tak wyglądał wkład Kantorowicza do „anonimowej kariery” Carla Schmitta i jego Teologii politycznej po II wojnie światowej w USA (zob. także Taubes 2013a: 434).

Za uczniem Schmitta, Ernstem-Wolfgangiem Böckenfördem (20052006), wyróżnijmy trzy wymiary „teologii politycznej”, z których każdy odnajdziemy u Bourdieu.

1. Prawna teologia polityczna. W najwęższym znaczeniu teologia polityczna przybiera dwie formy: genetyczną i strukturalną (zob. także Gierycz 2007). W pierwszym rozumieniu to transfer pojęć teologicznych do sfer nieteologicznych (zadaniem naukowca jest wtedy rekonstrukcja genezy zsekularyzowanych pojęć), a w drugim - powielenie struktury myśli teologicznej w nowym obszarze (zadaniem naukowca jest wówczas rekonstrukcja analogii między pojęciami teologicznymi i zsekularyzowanymi; Schmitt 2000: 6061). Ponieważ Schmitt skupia się przede wszystkim na transferach pojęć teologicznych w dziedzinę prawa (zob. także Schmitt 2014), Böckenförde mówi w tym kontekście o prawnej teologii politycznej. Wydaje się jednak, że nie ma potrzeby zawężania analiz pojęciowych tylko do sfery prawa. Podobne transfery moga zachodzić między teologia a nauką (socjologia, psychologia, antropologia, ekonomią itd.). Jest to tym bardziej uzasadnione, gdyz - jak zauważa Schmitt (2000: 62) - w wieku XX socjologia zajęła miejsce prawa naturalnego, a zatem prawna teologia polityczna powinna zostać zastąpiona teologią socjologiczną ${ }^{6}$. Takie mnożenie rozwiązań terminologicznych nie służy jednak jasności. Z tego powodu lepiej mówić po prostu o socjologii teologii i pojęć teologicznych, Begriffsgeschichte czy o „semantyce historycznej”, która skupia się z konieczności na sekularyzacji poszczególnych pojęć (Koselleck 2001). Do

\footnotetext{
${ }^{6}$ Sam Schmitt pierwsze trzy rozdziały, które później weszły do książkowego wydania Teologii politycznej, opublikował początkowo w Festschrifcie dla Maxa Webera Gtówne problemy socjologii pod tytułem Socjologia pojęcia suwerenności a teologia politycæna. Istnieje głęboki związek między wizją nowoczesnego państwa i świata Webera jako „żelaznej skorupy” (w kontekście gnostyckim takie tłumaczenie tej metafory jest znacznie bardziej trafne niż ,żelazna klatka”) a wizją Schmitta (Taubes 2013: 175-186, 430-431). Otwiera to pole analiz wcześniejszego transferu między polem socjologicznym a prawnym i teologicznym.
} 
tej dziedziny Kantorowicz wprowadził ważne novum, skupiając się nie tylko na pojęciach, ale przede wszystkim na metaforach, oraz podkreślając, że tak jak pojęcia teologiczne są sekularyzowane, tak też pojęcia polityczne bywają teologizowane. Transfer między tymi sferami jest zatem obustronny. Tę intuicję zawdzięczał być może wielkiemu krytykowi Schmitta, Erikowi Petersonowi.

2. Instytucjonalna teologia polityczna. Ten rodzaj teologii dotyczy związków między religią a porządkiem politycznym, a w szczególności - między Kościołem a państwem. Należy do niej kwestia religijnej legitymizacji/delegitymizacji polityki i politycznej legitymizacji/delegitymizacji religii. Według Böckenfördego najwybitniejszym dziełem z tego zakresu jest Państwo Bože św. Augustyna.

3. Apelatywna teologia polityczna. Ostatni rodzaj teologii politycznej dotyczy idealnego ładu politycznego, który wynika z orędzia religijnego. Twórcą tego typu teologii politycznej, w tym wypadku o bardzo silnych skłonnościach lewicowych, jest Johann Baptist Metz (2000).

O ile definicja prawnej teologii politycznej nie budzi wątpliwości, o tyle Böckenförde ma problem z odróżnieniem dwóch pozostałych rodzajów teologii politycznej. Państwo Boł̇e nie tylko odnosi się do związków między polityką a Kościołem, ale również rysuje pożądany obraz ładu politycznego. Z kolei prace Metza (2000) nie tylko dotyczą wyobrażeń idealnego ładu, lecz także obracają się wokół Kościoła jako instytucji i jego związków ze społeczeństwem. Trudno zatem dopatrzyć się fundamentalnych różnic w strukturze myśli Augustyna i Metza i trudno traktować reprezentowane przez nich teologie jako fundamentalnie różne. Wynika to zresztą wprost z analiz Böckenfördego (2005-2006: 307), który twierdzi, wbrew Petersonowi, że teologia chrześcijańska zawsze jest teologia polityczna, albowiem musi wypowiadać się o świecie.

Ponieważ teologia instytucjonalna i apelatywna są teologami chrześcijańskimi, różni je nie to, co mówią, ale - skąd mówią. Ponieważ rozważania Schmitta zostały poświęcone Weberowi, w poszukiwaniu jasnego principium divisionis dobrze będzie powołać się na jego rozróżnienia (kluczowe dla Bourdieu) między czarownikiem, kapłanem i prorokiem. Pierwszy rodzaj teologii politycznej jest teologia czarownika, który zmienia znaczenie słów. Drugi - to teologia kapłanów, ortodoksów, teologia odgórna, która legitymizuje rzeczywistość oficjalnych instytucji (św. Augustyn występuje tutaj jako kapłan). Trzeci wreszcie jest teologia proroków, heretyków, teologią oddolną, która mobilizuje do zmiany rzeczywistości (Johann Baptist 
Metz jest $\mathrm{w}$ tym sensie prorokiem). Tak uporządkowana typologia pomoże nam w zrozumieniu teoretycznego projektu Bourdieu.

\section{/// Teologia prawna}

Autor Dystynkcji - jak wcześniej już sugerowałem - uprawia wyrafinowany rodzaj prawnej teologii politycznej (socjologii teologii), śledząc, w jaki sposób pojęcia teologiczne zastępowane sa pojęciami sekularnymi, i dochodzi on do tych samych wniosków, co Schmitt i Kantorowicz. W nowych czasach Bóg jako absolut zastępowany jest szeregiem innych podmiotów, które pretendują do statusu absolutnego. Ten proces zachodzi, z jednej strony, w polityce, w której miejsce Boga zajmuje dana klasa społeczna, freischwebende Intelligenz (Bourdieu i Wacquant 2001: 101), świat, historia, Społeczeństwo (2006: 163-164, 342) i last but not least - Państwo; z drugiej zaś - w filozofii i nauce, które zastępują Boga wrodzonymi ideami (Kartezjusz), podmiotem transcendentalnym (Kant), językiem i komunikacją (Habermas), logiką (pozytywizm) i gramatyką (Wittgenstein; Bourdieu 2004c: 1-2). Nie chodzi tutaj jedynie o proces genezy, ale również o homologię. W szczególności Bourdieu odkrywa podobieństwo Absolutu oraz naukowego i politycznego suwerena. Opisując tego ostatniego, czerpie z religijnej retoryki i widzi Państwo jako „stwórcę”, „niepojmowalny obiekt”, „punkt widzenia nad innymi punktami widzenia”, „władzę nad władzami” (Bourdieu 2014).

Co ciekawe, Bourdieu przeprowadzając genealogię pojęć, którymi się posługujemy, podchodzi sceptycznie do przeprowadzania genealogii pojęć, którymi sam się posługuje. Analizuje on strukturę i genezę (historia strukturalna) poszczególnych pól, ale na własnym poletku nie życzy sobie, by analizować genezę, lecz jedynie strukturę. Jak przekonuje, „habitus”, ,pole”, „kapitał” „nie są wynikiem teoretycznej partenogenezy, ich porównywanie ze sposobami, w jakie były używane wcześniej, niewiele wnosi. Powinny być oceniane w kontekście praktyki badawczej, bo zrodziły je praktyczne problemy przedsięwzięć badawczych" (Bourdieu i Wacquant 2001: 155). Bourdieu instynktownie czuł, że genealogia pojęć teoretycznych odbiera im prawomocność. I tak było w istocie, gdy Raymond Boudon (2003) krytykował pojęcie „habitusu” u Bourdieu jako nieuprawnione uproszczenie pojęcia habitusu u św. Tomasza albo gdy w podobnym kontekście Flanagan (2007: 97-98) dowodził wyższości podejścia Panofskiego. Podobne relatywizujące konsekwencje miałaby metaforologiczna analiza teorii Bourdieu, która mogłaby pokazać, że np. korzystanie z metafor pochodzących z róż- 
nych pól: ekonomicznego („,kapitał”), religijnego („habitus”) i naukowego (,pole”), prowadzi do napięć (zob. także Pawlik 2013).

Aby ustrzec się przed tego typu krytykami, autor Dystynkcji dokonuje zabiegu, który znamy z wymiany zdań między Carlem Schmittem a Hansem Blumenbergiem (zob. także Grad 2013, Sosnowska 2013). Blumenberg odrzucał prawną teologię polityczna, gdyż implicite zawarte w niej było pojęcie sekularyzacji, ono zaś znów zakładało, że zsekularyzowane pojęcia sa pojęciami zafałszowanymi i niepełnymi w stosunku do teologicznych oryginałów. Widział, że przeprowadzenie genealogii pojęć odbiera im prawomocność (ta prawnicza kategoria była fundamentalna dla Blumenberga i Schmitta, ale także dla Bourdieu; zob. także Rey 2007). Aby bronić nowoczesnych pojęć przed Schmittowską krytyką, dowodził, że są one odpowiedziami na pytania, które zadaje absolutna rzeczywistość, na które teologia nie mogła udzielić satysfakcjonującej odpowiedzi. Na podobnej zasadzie Bourdieu pragnie nas przekonać, że jego teoria udziela prawidłowej odpowiedzi tam, gdzie poprzednie teorie były bezradne. Przesunięcia znaczeniowe pojęć teoretycznych nie są zatem ważne, ważne jest to, czy owe pojęcia pozwalają odpowiedzieać na pytanie, które badaczowi zadaje rzeczywistość empiryczna. Tak jak Blumenberg głosi, że nowoczesność uprawomocnia się sama, tak u Bourdieu uprawomocnia się sama teoria. O ile jednak Blumenberg delegitymizuje teorie, krytykujące nowoczesność, o tyle Bourdieu odbiera legitymizację rzeczywistości, którą krytykuje jego teoria.

\section{/// Teologia instytucjonalna i apelatywna}

Istnieje antyrzymski afekt, którym żywi się niechęć Bourdieu do Kościoła, papiestwa ${ }^{7}$ kleru${ }^{8}$. Ponieważ francuska socjologia narodziła się z ducha antyklerykalizmu, wzmocniła ona - jak samokrytycznie zauważa Bourdieu - jego upośledzenia, które odziedziczył po sekularnej tradycji (Dianteill 2003: 546). Głosił on wręcz, że socjolog religii nie może być socjologiem religijnym (tamże: 544). Być może właśnie status „republikanina" i antyklerykała jest niezbędny, aby zająć wysokie miejsce we francuskiej nauce, choć wciąż można znaleźć takie wyjątki jak Chantal Delsol czy Alain Besançon. Tak czy inaczej, jeśli francuski badacz odwołuje się

\footnotetext{
Bourdieu skarżył się na przykład Wacquantowi, że w czasach Jana Pawła II zaczynają dominować fałszywe filozofie duchowe, idealistyczne i personalistyczne (Bourdieu, Wacquant 2001: 177).

${ }^{8}$ Bourdieu (2009: 152-160) niezwykle irytował „śmiech biskupów”, którym przykrywali rzeczywisty wyzysk ekonomiczny świeckich pracowników Kościoła, a także zależność od finansowego wsparcia ze strony państwa, jak podczas pierwszej pielgrzymki Jana Pawła II do Francji (s. 129).
} 
do symboliki chrześcijaństwa, to najczęściej dla celów antychrześcijańskich (zob. także Girard 2006: 52).

Krytyka Kościoła przez Bourdieu przypomina jego krytykę państwa, a to z tego powodu, że - jak podkreślał Schmitt (2000: 86) - istnieje daleko posunięta analogia pomiędzy Kościołem a państwem, między uniwersalizmem Kościoła a uniwersalizmem rzymskiego imperium. W tym sensie Kościół jest wyjątkową polityczną instytucją. Bourdieu zgadza się z tą diagnoza, pokazując, że Kościół i państwo łączy to, że dążą one do monopolu na przemoc symboliczna, którą socjologia musi ujawnić. Kwestię instytucjonalnej teologii politycznej Bourdieu rozwiązuje w inny sposób niż opisywani przez Schmitta liberałowie. Nie próbuje on przeprowadzić rozgraniczenia między religia a światem. Nie próbuje przekonać, że roszczenia religii i Kościoła powinny zostać ograniczone do sfery prywatnej. Jego strategia jest inna. Otóż zawiesza on różnicę między religia a światem i pokazuje, że w Kościele obowiązują te same reguły, co w innych polach społecznych, a więc że w ostatecznym rachunku - Kościół jest światem. Ponieważ rządzi nim ta sama logika kapitału, należy traktować go jako przedsiębiorstwo (w tym wypadku przedsiębiorstwo religijne), które bierze pod uwagę interesy klientów (laikatu) oraz pracowników (zatrudnionych w Kościele), a także popyt (w tym wypadku popyt religijny), usługi (ortodoksyjne i heretyckie) oraz podaż (w tym wypadku podaż religijna) (zob. także Bourdieu 2009: 152-160, Rey 2007, Warczok 2010).

Z tego punktu widzenia Bourdieu dokonuje analizy genezy i transformacji pola religijnego i powolnego zdobywania monopolu na zarządzanie kapitałem religijnym przez kapłanów. W jednej ze swoich wczesnych analiz, która przeprowadził razem z Monique de Saint Martin (1982), zbadał episkopat francuski, rekonstruując jego strukturę klasowa i pokazując walki w jego obrębie. Na gruncie polskim podobnie uczynił Tomasz Warczok (2010), sprowadzając spór między tzw. otwartym i zamkniętym Kościołem do gier władzy.

Choć Bourdieu zawiesza roszczenia religii i Kościoła na innej drodze niż liberałowie, to w ostatecznym rachunku idzie on śladem krytyki, jaką opisywał Schmitt (2000: 84-85). Chodzi tu o niechęć do „niedającej się uchwycić politycznej siły rzymskiego katolicyzmu”, „bezgranicznego oportunizmu”, „hierarchicznego aparatu administracji o monstrualnych rozmiarach, którego głównym celem jest kontrolowanie życia religijnego i który kierowany jest przez ludzi pryncypialnie odmawiających posiadania rodziny". 
Teologia prawna Bourdieu ujawniła ukryte działania „magii prawdy”, którą stosuja , „zarownicy” władzy, sprawiając, że Bóg staje się absolutnym suwerenem (w polityce) i absolutnym obserwatorem (w nauce). Teologia instytucjonalna Bourdieu pokazała z kolei walkę w obrębie instytucji kościelnych i przemoc symboliczną stosowaną przez kapłanów. Francuski socjolog nie staną jednak po stronie teologii apelatywnej i proroków, którzy ja głoszą. W walce pomiędzy ortodoksami a heretykami nie staje bowiem po żadnej ze stron, a jedynie opisuje ich strategie: z jednej strony, strukturalny konserwatyzm ortodoksów, a z drugiej - heretyckie odwołania do źródeł, mesjanizmu i ascezy, a więc początkowych zasad, jakie obowiązywały w polu religijnym. W ten sposób Bourdieu wygasza mobilizacyjny potencjał religii, ujawniając jej strukturalne determinanty. Idzie tutaj tą samą drogą, co Durkheim i jego szkoła, która rozpoczęła od analiz religii, aby zneutralizować dominujący wtedy sposób konstruowania rzeczywistości społecznej. Dla Bourdieu (1993: 28) istota socjologii polega na translacji religijnych i metafizycznych problemów w problemy, które mogą być analizowane naukowo i w konsekwencji - politycznie.

Korzystając z prawnej teologii politycznej (socjologii teologii), Bourdieu dekonstruuje instytucjonalną i apelatywną teologię polityczną. Uprawia zatem coś, co można by określić jako negatywną teologię polityczną. Pozornie jego teorią rządzi ironiczne traktowanie pojęć religijnych, ale w rzeczywistości układają się one w religijną konstelację. Świat, który przedstawia Bourdieu, jest światem, w którym (dobry) Bóg został zastapiony przez (złe) Państwo (pokazuje to socjologia teologii). W konsekwencji Państwo nabiera cech „złego Boga”, od którego nie możemy się uwolnić, gdyż dobrego Boga nie ma - nie widza go ani ortodoksi, ani heretycy (dekonstrukcja teologii instytucjonalnej i apelatywnej). Na poziomie metafor religijnych Bourdieu zbliża się do gnostyckiej wizji świata, w którym panuje zły demiurg i od którego nie zbawi nas daleki Bóg.

Gnostycki światopogląd Bourdieu rezonuje z wizjami bohaterów, na których się powołuje i z którymi dzieli fundamentalne doświadczenie wyobcowania ze społeczeństwa: Kafką i Pascalem. Moglibyśmy dodać tutaj także Kantorowicza i Panofskiego. W trakcie pracy nad Dwoma ciałami króla

\footnotetext{
${ }_{9}$ Dalsza analiza kryptoteologii Bourdieu wymagałaby także uwzględnienia Sartre’a i Heideggera, myślicieli niezwykle dla niego ważnych, którzy zostali uznani przez Hansa Jonasa (1994: 349-357) za czołowych przedstawicieli współczesnej recydywy gnostycyzmu. Podobnie należałoby spojrzeć na Karla Marksa: pojęcie alienacji, które uczynił fundamentem swojej teorii, ma bowiem rodowód gnostycki (zob. także Taubes 2013a: 206). Ważnym punktem odniesienia byłby także św. Augustyn, który z gnozą nieustannie się zmagał i do którego - poprzez Pascala - Bourdieu z konieczności powraca, na własny sposób opisując civitas terrena i civitas Dei, dochodząc do koncepcji civitas terrena $D e i$. $\mathrm{Na}$ inną okazję pozostawiam analizę głębokiego związku między Bourdieu a Girardem, któ-
} 
Kantorowicz spędził upojny wieczór z Erwinem Panofskim. Kiedy opuszczał dom, spojrzał w niebo nad nimi: „Kiedy patrzę na gwiazdy, czuję moją marność”, na co odparł Panofsky: „Wszystko, co czuję, to marność gwiazd” (zob. także Panofsky 1997: 190). Poczucie marności człowieka i jednocześnie poczucie marności kosmosu jest tym, co charakteryzuje gnozę (Jonas 1994: 345). O ile jednak Kantorowiczowi i Panofskiemu dana była jedynie część tego doświadczenia, o tyle Kafka i Pascal odczuwali je w całej grozie.

\section{/// Kafka}

Twórczość Kafki była dla Bourdieu przełomowa, albowiem naprowadziła go na homologię między teologia a socjologią. Tylko pozornie największe powieści Kafki nie dotyczą teologii, już bowiem dla pierwszych interpretatorów było jasne, że najbardziej trafne jest ich ezoteryczne, teologiczne odczytanie. Max Brod (1982: 72) twierdził, że jedyną właściwa kategorią do zrozumienia życia i dzieła Kafki jest „świętość”. W kluczu teologicznym odczytywali je także Gershom Scholem i Walter Benjamin (Scholem 2006: 286-311). Ten pierwszy uznał Księgę Hioba za podstawowy punkt odniesienia Procesu, w którym ukazany został niesprawiedliwy, niezrozumiały i nieodwołalny wyrok. Ten, który ów wyrok wydał, obecny jest na kartach książki jako „nicość objawienia”. „Objawienie” w tym świecie jest zredukowane do zera (w tym sensie jest nicościa), choć dalej nie zanika i trwa jako ślad, puste miejsce (w tym sensie pozostaje objawieniem). Takie objawienie nie pozwala nam wyrwać się z demonicznego świata. Jedyną nadzieją, jaką daje nam Kafka, jest - według Benjamina słaby mesjanizm, zawarty w kategorii „nawrotu” i ,studiowania” (Scholem 2006: 290).

Tropem tych teologicznych odczytań Benjamina i Scholema poszedł w swym klasycznym studium Karl Erich Grözinger (2006: 15), który dowodził istnienia głębokich związków między myślą Kafki a kabałą.

Kabała - pisał - podobnie jak średniowieczny platonizm, pojmuje stopniowanie świata jednocześnie jako hierarchię jakości. Niebiańskie szczeble, które znajdują się bliżej ludzkiego świata, sa z tego powodu bliższe jakości życia doczesnego, niż stojące nad nimi stopnie wyższe. I biada modlitwie, biada duszy, które nie prze-

rych łączy swoisty jansenizm (zob. także Flahault 2013) oraz augustyńska antropologia (zob. także Carnevali 2013). 
dzierają się wzwyż, bo przydarzy im się to, co przeżyli obydwaj bohaterowie Kafki - Józef K. i geometra K. Jeden ma wprawdzie do czynienia z sądem, drugi z biurokracją zamku, ale to, co tam widzą, nie różni się prawie od ich własnego, nędznego świata. W obydwu tych wielkich powieściach, w Procesie i w Zamku, autor przedstawia zatem kryzys kabały, niepowodzenie teurgii, niezdolność człowieka do przedarcia się własnym działaniom ku górze, przed decydująca, najwyższą instancję.

Grözinger (2006: 248) dostrzegał związek kabały z gnozą. Nie zgadzał się jednak z interpretacją Günthera Andersa, który - widząc w Kafce marcjonistę - dowodził, że wierzy on w Boga, ale w złego Boga, Boga Starego Testamentu, Boga prawa i zła. Tymczasem ,w kabale z owych «złych» przejawów Boga nie powstaje zły Bóg. Bóg kabalistów - wyniesiony wysoko ponad niskość świata, deus absconditus, [...] może porozumiewać się z brudną rzeczywistościa świata jedynie pozbywając się swej wielkości i zbliżając się do nizin”. Na tezę Andersa powołuje się również Taubes (2013b: 206-207): „Prawo i obyczaj stanowią dla Kafki religię. Religia oznacza rytuał, lecz w sytuacji agnostycznej rytuał staje się czymś tyrańskim. Rytuał może trwać po wygaśnięciu prawa i woli jego twórcy, a wykonywanie go jest aktem samoupokorzenia. Przykazania maja sens wyłącznie jako czyjeś nakazy i obowiązują dopóty, dopóki sankcjonuje je ich stwórca. Paradoks Kafki polega na tym, że Bóg umarł, lecz jego przykazania wciąż obowiązują. Kafka jest ateista, który swój ateizm przekształca w teologię. Wykształconemu w metodzie dialektycznej Andersowi nie udaje się jednak, jak sądzę, przeniknąć do najgłębszej warstwy dialektyki Kafki, do eksperymentu takiej radykalizacji ateizmu, by na jaw wyszła «niezniszczalna» podstawa bytu".

W opisie brudu rzeczywistości i tyrańskich rytuałów instytucji, które przetrwały po śmierci Boga, Bourdieu powinien się bez trudu odnaleźć. W pewnym sensie był on nawet bardziej konsekwentnym marcjonista niż Kafka. Przejawy złego świata jak najbardziej kierowały jego uwagę na złego Boga, którym jest Państwo. Państwo było zarazem Bogiem obcym, dalekim, innym, który bynajmniej nas nie zbawia, ale zniewala. Francuskiego socjologa nie zadowoliłaby formuła „nicości objawienia”. Dla niego nie istnieje bowiem żadne inne objawienie poza objawieniem władzy Państwa, jedynej, decydującej, najwyższej, a jednocześnie nieuchwytnej i ostatniej instancji. Ale jednocześnie jego ateizm jest tak zradykalizowany, odbywa się tutaj tak silna praca religijnej metafory, że jego myśl „przekształca się w teologię" i poszukuje „niezniszczalnej podstawy bytu”. 
Wizja złego świata, zhierarchizowanego, podzielonego między poszczególne instancje, z których najważniejsza jest władza Zamku i Sądu, musiała bardzo silnie przemawiać do Bourdieu. Swoją kluczowa pracę (mimo że Kafce pozostawił w niej ostatnie słowo) poświęcił jednak Pascalowi, ogłaszając się jego uczniem (Bourdieu 2006: 8), a nawet więcej - „pascalianinem" (pascalien). Medytacje pascaliańskie są zatem w istocie wyznaniem pascalianina. Nikt nie docenił radykalizmu i paradoksalności tego gestu: oto antyklerykał i ateista opowiedział się za największym apologetą chrześcijaństwa.

\section{/// Pascal}

Mimo że Bourdieu podaje wiele argumentów na rzecz własnego związku z Pascalem, wydaje się, że najbardziej decydujący jest ten sam powód, który zbliżył go do Kafki: wspólna wizja świata. Projekt Pascala polegał na udramatyzowaniu ludzkiej egzystencji, na pokazaniu nędzy, a jednocześnie wielkości człowieka ${ }^{10}$. Francuski socjolog dostrzega jednak tylko jedna jego stronę: nędzę. Dzieje się tak dlatego, że interpretuje Pascala jako myśliciela, który „rezygnuje z ambicji posiadania podstaw” (Bourdieu 2006: 8). Tymczasem Pascal nie jest przedstawicielem samougruntowującej się nowoczesności. On nie tylko szuka podstawy, ale ja znajduje. Ta podstawa jest Bóg Abrahama, Izaaka i Jakuba. Dla autora Myśli człowiek jest nędzny bez Boga, ale wielki z Bogiem: „Znajomość Boga bez znajomości własnej nędzy rodzi pychę. Znajomość własnej nędzy bez znajomości Boga rodzi rozpacz” (Pascal 1989: 53). Bóg Pascala jest Deus absconditus: „Gdyby nie było ciemności, człowiek nie czułby swego skażenia” (1989: 333). Świat jest skażony, leży we złem. Zbawić nas może jedynie całkowicie inny Bóg. Chrześcijańskie objawienie zawiera w sobie naraz te dwie skrajności: „Znajomość Chrystusa stanowi pośrodek, ponieważ w niej znajdujemy i Boga, i swoją nędzę” (1989: 53). „Wiara chrześcijańska dąży do ustalenia tych rzeczy: skażenia natury i odkupicielstwa Chrystusa" (1989: 171). Chrystus jest naszą jedyną drogą do Boga, który się ukrywa.

Choć Pascal nie był filozofem społecznym, są u niego obecne intuicje, które Bourdieu od razu podchwycił. Leszek Kołakowski (2001: 239) cytuje następujący fragment Myśli jako najbardziej skondensowany Pascalowy opis polityki: „Wszyscy ludzie ze swej natury nienawidzą się wzajem. Posłużono się, jak się dało, pożądliwościa, aby jej kazać służyć powszechnemu dobru;

${ }_{10}$ To oczywiście klasyczny wątek chrześcijaństwa, który ma swoje korzenie w księdze Koheleta (zob. także np. Domański 1997). 
ale to tylko sztuczka i fałszywy obraz miłości bliźniego; w gruncie rzeczy bowiem to tylko nienawiść. [...] Ugruntowano wszystko na pożądliwości i dobyto z niej cudowne prawidła porządku, moralności i sprawiedliwości; ale w głębi, tej szpetnej głębi człowieka, owo figmentum malum jest tylko przykryte, ale nie usunięte”. Pascal, tak jak przed nim św. Augustyn, desakralizuje wszystkie instytucje polityczne, obnaża przemoc, na której są ufundowane. Ta intuicja wypowiedziana jest jeszcze dobitniej we fragmencie 230 Myśli, w którym opisane sa praktyki prawodawców, ukrywających „mistyczny fundament władzy” ( fondement mystique de l'autorité, co Boy (1989: 130) oddaje jako „tajemniczą zasadę jego powagi”): prawa trzeba „wpoić jako uprawnione, wiekuiste i ukrywać ich początek, jeżeli się nie chce, aby rychło znalazły koniec" (Pascal 1989: 131). Pascal jednocześnie ukazuje marność „ja”, które pragnie zastapić Boga. Rezygnuje tutaj ze wszelkiej teodycei, nie próbuje racjonalizować zła. Tym śladem idzie Bourdieu, który nie akceptuje żadnego teologicznego (teodycea) ani socjologicznego (socjodycea) uzasadnienia „cierpienia społecznego”. Nie da się usunąć figmentum malum, skażenia natury, nędzy człowieka i nędzy świata, la misère du monde.

Pascal stoi u początków nowożytnego kryzysu gnostyckiego (Jonas 1994: 339-342), ale broni się przed „pokusą gnostycką” (Kołakowski 2001: 122-143), znajdując nadzieję w Bogu. Ponieważ Bourdieu nie ma takiej nadziei, nie wierzy w „człowieka z Bogiem” i „odkupicielstwo Chrystusa” (albowiem Bóg został zastapiony przez suwerena, „boga śmiertelnego”), musi tej pokusie ulec; musi ulec rozpaczy. Podobnie jak radykalizuje wizję Kafki, tak też radykalizuje wizję Pascala.

Wszystkie sposoby wydostania się z „nędzy świata”, jakie opisuje Pascal, sa przez Bourdieu zdekonstruowane i odrzucone jako fałszywe. Chrześcijańskie cnoty kardynalne - wiara, nadzieja i miłość - u Bourdieu przestaja być cnotami. Nie tylko nie pozwalają nam opuścić kamiennego świata, ale jeszcze mocniej w nim nas więżą. Wiara u Bourdieu jest przede wszystkim wiarą w illusio, grę społeczną. Wierzenie jest „indywidualną złą wiarą utrzymywaną i podsycana przez kolektywną złą wiarę" (2007: 266). Z kolei nadzieja jest dostosowaniem naszych subiektywnych wyobrażeń do obiektywnych możliwości, jakie narzuca nam nasz habitus (Bourdieu 2006: 209). Wreszcie miłość - tak ważna dla Pascala i Augustyna - jest dla socjologa zdaniem sobie sprawy z konieczności, jest miłością przeznaczenia klasowego, która reprodukuje nierówności (Bourdieu 2004b: 129, Bourdieu 2005, zob. także Gdula 2009)11. Pascalowska podwójna predestynacja,

${ }^{11}$ Byłby to powrót do gnostyckiej wizji świata, w którym rządzi ślepe fatum. Sprzeciwiał się jej św. Augustyn, głoszący przeciw amor fati - amor Dei i płynąca stąd odpowiedzialność człowieka: Ego, 
która sprawia, że jeśli chcemy w wolności czynić dobro, w rzeczywistości nasza wola jest „przymuszana” do tego przez Boga (Kołakowski 2001: 46), u Bourdieu została zimmanentyzowana. Miejsce suwerennego Boga, który czyni naszą wolną wolę konieczną, zajęło Państwo. W tym kontekście Bourdieu wielokrotnie odwołuje się do amor fati (Bourdieu 2006: 208), akceptacji „przygniatającego, kosmicznego losu” (Jonas 1994: 345). Pascal pisze także o roli cudów w dowodzeniu prawdy chrześcijaństwa. Dla Bourdieu cud jest wyjątkiem, który dopuszcza państwo, kiedy np. zezwala, a nawet promuje „cudowne dzieci” (les miraculés) z klas niższych w swoim systemie edukacyjnym. Taka praktyka jednak nie podważa społecznej reprodukcji, ale wręcz ją wzmacnia. Bourdieu (2009: 30) porównuje ten system do demona, który sortuje uczniów, utrzymując między nimi różnice. Bezinteresowny dar, który odgrywa tak dużą rolę w myśleniu religijnym, jest dla socjologa (Bourdieu 2009: 131-160) jedynie zasłona dla prawdziwych gier władzy. Natura (physis) jest skażona, a łaska (charisma) jedynie to skażenie ukrywa (Bourdieu 2006: 344). Symbol nie odsyła, jak u Augustyna, do Boga, ale do przemocy, przemocy symbolicznej, na którą monopol zdobywa Państwo. Jezus Chrystus i Matka Boska nie są w stanie nas wybawić z przemocy i naszych popędów, gdyż sama wiara w ich przedstawienia jest efektem przemocy symbolicznej i transferu pierwotnego libido na instytucje (Bourdieu 2006: 233-234).

\section{/// Medytacje kartezjańskie}

Bourdieu nie chce jednak pogodzić się z „nędzą świata”, ale nie szuka ocalenia w Bogu ani w żadnym religijnym symbolu. Moc Państwa i Społeczeństwa jest tak duża, że prowadzi do naszej niewiedzy (agnosia; zob. także Jonas 1994: 345). Punkt oparcia, którego poszukujemy w nas samych, nieustannie się oddala. Nasze fizyczne ciało (physis) jest tylko zsomatyzowaną dominacja (Bourdieu 2004b: 34), nasza dusza (psyche) idzie jedynie za ciałem i sprawia, że człowiek wchodzi (ciałem i dusza) w ,swoją funkcję, czyli w swoją społeczną fikcję" (2006: 347). Jeśli jest jakaś wolna cząstka w człowieku, to musi być ukryta i niemożliwa do określenia. Takiej cząstki poszukiwali gnostycy i nazywali ją duchem (pneuma), ,iskra pochodząca spoza świata". W tym sensie odpowiednikiem niebiańskiego, absolutnie innego Deus absconditus jest na ziemi homo absconditus (Jonas 1994: 341-342, $351)$.

inquit, ego dixi, non diabolus, non fortuna, non fatum. 
Bourdieu oczywiście nie przejmuje tego metafizycznego punktu widzenia, ale struktura jego myśli przypomina strukturę gnostycką. Cały jego projekt można odczytywać jako próbę odnalezienia podstawy bytu, „wolnej cząstki" w człowieku, której nie determinowałaby przemoc symboliczna. Nie odnajduje jej ani w ciele, ani w duszy. Poszukuje owej ukrytej i niemożliwej do określenia wiedzy na drodze socjoanalizy. I proponuje nam coś w rodzaju Medytacji o filozofii pierwszej, przy czym miejsce, które u Kartezjusza zajmowała filozofia, u niego należy rzecz jasna do socjologii.

Jak wiadomo, Kartezjusz w kluczowym fragmencie Medytacji wprowadza hipotezę snu, która wtrąca go w radykalne wątpienie: w żadnym momencie nie możemy stwierdzić, czy śnimy, czy też nie. Na podobnej zasadzie Bourdieu (2004b: 8) zakłada istnienie hipnotycznej mocy dominacji, przy czym nie jest to żadna hipoteza, ale rzeczywistość. Dominacja wprowadza nas bowiem w rodzaj snu, w którym nie potrafimy odróżnić wolności od zniewolenia. W kolejnym kroku Kartezjusz radykalizuje swoje wątpienie i wprowadza figurę demiurga, złego ducha, zwodziciela (deus deceptor): „Przyjmę więc, że nie najlepszy Bóg, źródło prawdy, lecz jakiś duch złośliwy, a zarazem najpotężniejszy i przebiegły wszystkie swe siły wytęży w tym kierunku, by mnie zwodzić. Będę uważał, że niebo, powietrze, ziemia, barwy, kształty, dźwięki i wszystkie inne rzeczy zewnętrzne są tylko zwodnicza gra snów, przy pomocy których zastawił on sidła na mą łatwowierność". W Piernszej medytacji nie znajduje żadnej podstawy dla pewności, wszystko bowiem podlega radykalnemu wattpieniu, a w konsekwencji ogarniaja go „nieprzeniknione ciemności” (zob. także Descartes 2001: 45-47, 50). Ostatecznie Kartezjusz odnajduje oparcie w Bogu (tamże: 68-72), który sprawia, że można ufać temu, co widzi się ,jasno i wyraźnie” (tamże: 80). Krótko mówiąc, poznanie jest wątpliwe tylko dopóty, dopóki człowiek „,nie uzna, że został stworzony przez prawdziwego i nie umiejącego zwodzić Boga" (tamże: 319). W perspektywie Kartezjusza dobry i doskonały Bóg zneutralizował demiurga. Zły duch okazał się jedynie hipotezą, która przytacza się tylko po to, aby ją obalić. Nie mógł on przecież posiadać mocy Boga, „ponieważ niemożliwe jest, żeby Bóg był zwodzicielem” (Descartes 1998: 55).

Bourdieu zgadza się z Kartezjuszem, że należy uprawiać „,radykalne watpienie" (a nawet je zradykalizować, bo nigdy do końca nie uwolni nas z iluzji; Bourdieu 2006: 19) i że jedyną droga jest myślenie (albo, jak u Kafki, studiowanie), ale nie odnajduje żadnego stałego, absolutnego punktu oparcia. Odrzuca wszystkie próby rozwiązania problemów metody poprzez 
odwołanie do deus ex machina (Bourdieu 2006: 167). To, co jawi się nam jako „jasne i wyraźne”, jest dla francuskiego socjologa najbardziej podejrzane. Albowiem oczywistość jest jedynie efektem przemocy symbolicznej (Bourdieu 2006: 139-141). W tym sensie Państwo jest znacznie bardziej niebezpieczne niż kartezjański deus deceptor. Nabiera ono cech demonicznych. Nie jest hipotezą, założeniem, ale raczej źródłem wszystkich naszych hipotez i założeń, źródłem prawa (nomos), któremu nie można zaprzeczyć (Bourdieu 2006: 138). Ono rzeczywiście jest duchem złośliwym (a nawet ducha$\mathrm{mi}$ ), a zarazem najpotężniejszym i przebiegłym. Wytęża swe siły nie tyle, by zwodzić, ile zrodzić (boski intuitus originarius). Ponieważ człowieczeństwo jest jego produktem, Państwa nie można traktować jako czegoś zewnętrznego wobec nas, lecz jako część nas samych, która sprawia, że sami siebie zwodzimy i zaczynamy działać w logice self-deception (zob. także Bourdieu 2006: 274, Bourdieu 2009: 158).

\section{/// Wyzwolenie przez wiedzę}

Wydaje się, że nie ma żadnej instancji, która mogłaby nas od iluzji, jakie nam zsyła Państwo, uwolnić. Bourdieu wskazuje jednak na przynajmniej dwie niepewne, wysoce ryzykowne drogi wyjścia: wiedzę i miłość. W ten sposób wychodzi poza negatywną teologię polityczną i proponuje coś, co moglibyśmy określić jako negatywną teologię emancypacji, dla której nie określa pozytywnych warunków możliwości. Tutaj drogi pomiędzy nim a Pascalem na zawsze się rozchodzą. Ten ostatni pisał w Myślach (1989: 371):

„Wszystko, co jest w świecie, jest pożądliwością ciała albo pożądliwością oczu, albo pychą życia: libido sentiendi, libido sciendi, libido dominandi". Nieszczęsna owa przeklęta ziemia, którą te trzy rzeki ogniste raczej rozpalają niż wilżą! Szczęśliwi będący nad tymi wodami niezanurzeni, nieporwani, ale nieruchomi i niewzruszeni; niestojący, ale siedzący w niskiej i pewnej pozycji, z której nie podnoszą się przed światłem, ale spocząwszy w niej w pokoju, wyciągają rękę ku temu, kto ich ma podnieść, aby ich utrzymać stojących i niewzruszonych w przysłonkach świętej Jeruzalem, gdzie pycha nie zdoła ich już pokonać i obalić, a którzy wszelako płaczą, nie iż widza spływające wszystkie znikome rzeczy unoszone strumie- 
niem, ale przez pamięć swej drogiej ojczyzny, niebiańskiej Jeruzalem, którą wspominają bez ustanku w ciagu swojego wygnania! ${ }^{12}$.

Wbrew Pascalowi Bourdieu opiera swój projekt na „swoistej alchemii, dzięki której libido dominandi naukowca ulega koniecznej przemianie w libido sciendi" (Bourdieu i Wacquant 2001: 175). Dla Pascala byłaby to nie sublimacja, ale odrzucenie Boga i ulegnięcie logice świata (zob. także Wagner 2012). Tego zwrotu Bourdieu dokonuje jednak w pełni świadomie. Jego socjologia nie rości sobie prawa do posiadania absolutnego punktu widzenia. Odrzuca ona wszelkie „teologiczne i kryptoteologiczne rozwiązania” (2004c: 2). Nie potrzebuje żadnego „stwórcy wiecznych prawd i wartości” i podobnie jak nowoczesność u Blumenberga uzasadnia samą siebie (Bourdieu 2006: 163-164). Można bowiem - według niego - połączyć realistyczne widzenie świata naukowego w całej jego zmienności z realistyczną teoria wiedzy. Materialistyczne, historyczne widzenie świata, jakie proponuje, jest „radykalną formą śmierci Boga i wszystkich jego awatarów” (2004c: 2).

Taki metodologiczny ateizm ma swoją homologię w ezoterycznej, wyzwolicielskiej wiedzy, która wymaga powolnej inicjacji i całkowitej konwersji w postrzeganiu świata (Bourdieu 1990: 53), a także gnostyckiej wizji Boga, który umiera. Opisy Boga-stwórcy, Boga-prawa miały w gnostycyzmie zawsze charakter ironiczno-polemiczny. Śmierć Boga - przypomina Jonas (1994: 349) za Heideggerem - oznacza, że „świat ponadzmysłowy utracił zdolność powodowania realnych skutków". Inny, nieznany Bóg w niczym nie pomoże socjologowi, który musi mierzyć się z realnie działającym demiurgicznym Państwem, narzucającym człowiekowi arbitralne prawo (nomos) i kształtującym jego zdominowaną naturę (physis). Wywiera ono tak duży nacisk na naukę, że zagraża libido sciendi. W konsekwencji socjologowie - jak pamiętamy - zamiast analizować Państwo, „myślą państwowo".

W obliczu tak przemożnych sił socjologia, która ujawnia prawdę o Państwie, jawi się jako cud. Pascal (1989: 411) twierdził, że „,historia Kościoła powinna się właściwie zwać historią prawdy”. U Bourdieu Kościół zostaje zastąpiony przez socjologię. Tak jak ortodoksja u Pascala istnieje poza wszelkimi dualizmami, zawierając je w sobie, tak wszystkie dualizmy ma przezwyciężyć socjologia Bourdieu (2006: 17). Do jej opisu używa wprost języka i figur religijnych: „nawrócenie” (Kafkowski „nawrót”), „nowy człowiek”, „,nowe oczy”, a przede wszystkim - „zerwanie”. Zerwanie

${ }_{12}$ Pascal cytuje tutaj 1 list św. Jana $(2,16)$ : „Wszystko bowiem, co jest na świecie, a więc: pożądliwość ciała, pożądliwość oczu i pycha tego życia nie pochodzi od Ojca, lecz od świata”. 
z oczywistością świata społecznego, z tym, co jasne i wyraźne, jest dla Bourdieu (Bourdieu i Wacquant 2001: 252) „konwersją spojrzenia”. Zerwanie nigdy się nie kończy, bo prawda nieustannie się oddala. Nie otacza jej - jak dawniej - blask, lecz staje się czymś ukrytym. Bourdieu używa języka paradoksu, podkreślając, że prawda jest stawką naukowych walk. Ponieważ jest stawka, nigdy jej nie poznamy. Socjoanaliza nigdy się nie skończy.

Socjologia ma dać człowiekowi „nowe oczy” i w tym sensie staje się „filozofia początku” (Bourdieu i Wacquant 2001: 252). „Chodzi o stworzenie jeśli już nie «nowego człowieka», to przynajmniej «nowego spojrzenia», oka socjologicznego. A to nie jest możliwe bez prawdziwej konwersji, bez metanoia, przewrotu mentalnego, zmiany całej wizji świata społecznego". Choć Bourdieu odżegnywał się od profetycznego tonu, miał jasną świadomość, że tego typu wypowiedzi będa prowadzić do podejrzeń o „nauczanie profetyczne” i „żądanie konwersji osobistej” (Bourdieu i Wacquant 2001: 253). Mimo że socjologia nie poszukuje żadnego Boga, żeby ujawnić „boga śmiertelnego”, sama musi nabrać cech boskich.

Dopiero wtedy, gdy nastapi socjologiczna metanoia i socjolog stanie się „nowym człowiekiem”, człowiekiem duchowym, który odkrył wolną cząstkę, można ujawnić panujące nad nami „moce i zwierzchności” (zob. także Bourdieu 1988: 106), tzn. „boską” moc Państwa, posiadającego monopol władzy symbolicznej i fizycznej, który powołuje do istnienia wszystkie podmioty społeczne. Ukazanie „boskiej” mocy Państwa ukazuje ja jako arbitralną uzurpację. Teologie, które legitymizowały i wciąż legitymizują Państwo, zostaja zrelatywizowane. W tym duchu francuski socjolog ujawnia na przykład „bogobojną hipokryzję” (2009: 101) urzędników, która nakazuje im całkowicie oddać się własnej oficjalnej funkcji (bogobojność), co jednocześnie przynosi zarówno im, jak i Państwu realne korzyści, w tym przede wszystkim dalsze utwierdzenie monopolu władzy (hipokryzja).

\section{/// Zbawienie przez grzech}

Socjologiczna wiedza ma nas wyzwolić (zob. także Jonas 1994: 351). Kiedy ujawnia wszechobecna przemoc symboliczna, ofiarowuje człowiekowi potencjalnie „wyzwolicielską świadomość” (Bourdieu i Wacquant 2001: 212). Bourdieu nie proponuje jednak żadnego programu reform społecznych. Nie ma złudzeń: niekończąca się walka między heretykami i ortodoksami niczego nie rozwiąże. Sugeruje jednak inną drogę, swoista alchemię, dzięki której libido dominandi ulega przemianie w libido sentiendi. Ten proces rozpoczyna się od wycofania się ze świata - od zmiany samego 
siebie, która jest warunkiem wszystkich zmian. O ile droga do konwersji naukowej, do wiedzy wiodła przez pokorę i ascezę (zob. także Bourdieu 1996: 109-115), o tyle droga miłości jest antynomijna. Odpowiada to dwóm wersjom gnostycyzmu: ascetycznej i libertyńskiej (zob. także Jonas 1994, Rudolph 1995, Taubes 2013b).

W dodatku do Meskiej dominacji Bourdieu pokazuje, że obok nauki właśnie miłość może uwolnić nas od dominacji Państwa. I podobnie jak było to w przypadku nauki, do opisu miłości wykorzystuje język religijny, a nawet mistyczny. Kościół, który odwoływał się do kategorii daru i bezinteresowności, ulegał według Bourdieu jedynie samooszustwu. Kiedy jednak następuje transfer tych pojęć w pole miłości, Bourdieu (2004b: 132-133) dostrzega możliwość emancypacji:

Charakteryzujące miłość zawieszenie walki o władzę symboliczną określana przez poszukiwanie uznania oraz kolektywną skłonność do dominacji oznacza tu obopólne milczące uznanie własnej inności, prowadzące poza alternatywę egoizm/altruizm, a nawet dychotomię podmiot/przedmiot - do stanu „stopienia się” czy łączności, którą oddaje jedna z niemal mistycznych metafor: „dwoje zatraca się w sobie bez utraty siebie”.

W Aneksie do Meskiej dominacji Bourdieu (2004b: 141-147) dostrzega możliwość kształtowania się ruchu społecznego wokół tak pojętej miłości. Odrzuca przy tym ruch feministyczny, a swoje nadzieje pokłada w ruchu gejów i lesbijek, który niesie ze sobą największą nadzieję na zerwanie przemocy symbolicznej i stworzenie utopii, rozrywającej związek między seksualnościa a władzą. Ta obietnica nie polega na odwróceniu znaków z potępienia na afirmację LG, lecz na antynomijnym ,zatarciu swej własnej podstawy społecznej, tej samej, która sprawiła”, że ruch LG „mógł zaistnieć jako siła społeczna zamierzająca obalić dominujący porządek społeczny" (Bourdieu 2004b: 144). Podobnie jak w przypadku nauki, taka zmiana wymaga radykalnej „rewolucji symbolicznej”, a zatem - radykalnej metanoi.

Wiedza, którą ofiarowuje socjologia, pozwala ujrzeć prawo i porządek jako arbitralne. Seksualna polityka i utopia Bourdieu zmierza do tego, żeby to prawo przekroczyć i sprawić, żeby uznało ono „partykularność zawierającą własne zaprzeczenie" (Bourdieu 2004b: 144). Taka wizja aktywistów ruchu gejowskiego i lesbijskiego nadaje im charakter gnostyckich ludzi duchowych, którzy nie są częścią żadnego obiektywnego porządku, 
znajdują się ponad prawem, ponad dobrem i złem - i mocą swojej gnosis stanowią prawo sami dla siebie (Jonas 1994: 349-351, zob. także Scholem 1995: 78-141).

Podobnie jak Medytacje pascaliańskie, Meska dominacja ostatnie słowo pozostawia „Bogu” (Bourdieu 2004b: 132-133):

Milczące uznanie zachodzące we wzajemnej wymianie racji bytu czy też milczące świadectwo zaufania są niezliczonymi znakami wskazującymi na istnienie doskonałej wzajemności zamkniętej w miłosnej diadzie - pierwotnej, niepodzielnej jedności społecznej wyposażonej w moc symbolicznej samowystarczalności - władzy wygrywania z ograniczeniami nakładanymi zwykle przez instytucje i rytuały Społeczeństwa, tego ziemskiego odpowiednika Boga.

W przypisie do tego fragmentu Bourdieu odsyła do Medytacji i jeden jedyny raz w swoich pismach odwołuje się do teologii politycznej, pisząc o „teologiczno-politycznej funkcji instytucji i ich rytuałów” (Bourdieu 2004b: 133).

\section{/// Teologia polityczna IV}

Bourdieu odrzucając prawomocność chrześcijaństwa, pozbawił je Boga (Rey 2007). A chrześcijaństwo bez Boga (podobnie jak judaizm) szybko przekształca się w gnostycyzm. Aby zrozumieć ten proces, odwołałem się do trzech teologii Carla Schmitta. Ale jednocześnie stworzyłem teologię czwartą, którą można by nazwać dramatyczną. Podczas gdy Schmitt ograniczał się do analizy genealogii i homologii pojęć, ja wziąłem pod uwage także metafory (ale zob. także Schmitt 2008), a przede wszystkim - narrację. Teologia będzie powracała wszędzie tam, gdzie posługujemy się narracją dramatyczną, która oparta jest na konflikcie między dobrem i złem (zob. także Budzik 1997).

Dramat rozpoczyna się od dostrzeżenia zła w świecie (w chrześcijaństwie mowa jest o upadku, demonach, grzechu), następnie w dramacie ujawnia się kryzys, przesilenie, zmaganie zła z dobrem (resp. apokaliptyka), którego rozwiązaniem jest pojednanie (resp. zbawienie). Gnostycyzm stanowi wygaszenie dramatu. Tę różnicę dobrze widać u Pascala i Bourdieu. Pascal dramatyzuje rzeczywistość: podkreśla zło, apokaliptykę i w związku z tym niezbędność zbawienia, które może przynieść jedynie obcy Bóg. Bourdieu zatrzymuje się na poziomie zła, które nie 
wchodzi w apokaliptyczne zmaganie z zasadą dobra, albowiem już u samego korzenia wszelkie dobro zostało zneutralizowane przez Państwo. Państwo jest tym, co na samym początku powstrzymało apokalipsę. $\mathrm{Na}$ tym polega istota gnostycyzmu, który zgodnie z przenikliwą definicja Taubesa (2013a: 185) jest niespełnioną apokaliptyką.

Mimo że francuski socjolog uznawał się za ucznia Kafki i Pascala, w rzeczywistości jego wizja była - jak wykazywałem - znacznie bardziej radykalna. Poprzez szereg podwójnych zapętleń przeszedł on na teren myślicieli, którym „pokusa gnostycka” nie grozi tylko dlatego, że jej ulegli. Jest to teren myślicieli „reakcyjnych”, „kontrrewolucyjnych”, których Bourdieu jako rewolucjonista nie cytuje. Zresztą nie musi ich cytować, bo nie musi ich nawet znać. Struktura jego myśli jest podobna do struktury ich myśli nie dlatego, że z nich czerpie, ale dlatego, że walczy z podobnymi przeciwnikami, co oni. Paradoksalnie, Bourdieu znalazł się w podobnej sytuacji, co inny współczesny marcjonista, Walter Benjamin (zob. także Taubes 2013a: 187-202), który nawet jako zadeklarowany zwolennik materializmu historycznego nieustannie powoływał się na „reakcjonistów”. Najważniejszym z nich był Carl Schmitt (Taubes 2013a: 427-442) $)^{13}$.

Trzy teologie Carla Schmitta pozwoliły rzucić światło na teologię polityczną Bourdieu, ale związek między tymi dwoma myślicielami nie ogranicza się do tego, że kategorie Schmitta dobrze opisują światopogląd Bourdieu. Związek między nimi jest związkiem między dwoma światopoglądami, między dwiema teologiami politycznymi, które posiadają podobną strukturę dramatyczną.

Bourdieu i Schmitta łączy fundamentalna diagnoza rzeczywistości. Każdy z nich neutralizuje na swój sposób apokalipsę, przy czym Schmitt jest antyapokaliptykiem jako prawnik, a Bourdieu jako socjolog. Pierwszy myśli antyapokaliptycznie, od góry, od strony potęg, które chronią nas przed chaosem, drugi - postapokaliptycznie, od dołu, od strony człowieka, który uległ potęgom. W centrum ich wizji świata stoi sakralizowane Państwo. O ile Bourdieu powołuje się na Hegla, Durkheima i Webera, o tyle Schmitt sięga głębiej do źródeł „myśli państwowej” - tzn. do Hobbesa. Mimo że Bourdieu Hobbesa w zasadzie nie przywołuje, to poprzez mechanizm podwójnych sprzężeń zaczyna mówić jego

\footnotetext{
${ }^{13}$ Jak podkreśla Taubes, komentatorzy Benjamina sumiennie zacierają jego niepokojące związki z myśla „reakcyjną”. Dzieje się tak również na gruncie polskim, gdy w swojej interpretacji Benjamina Adam Lipszyc (2012) ani razu nie przywołuje Schmitta.
} 
językiem ${ }^{14}$. Pascal widzi wolność człowieka, Bourdieu i Hobbes dostrzegaja przymus: „Każdy akt woli człowieka - pisał ten ostatni - każde jego pragnienie i każda skłonność wypływa z jakiejś innej przyczyny, ta z kolei z innej przyczyny w nieprzerwanym łańcuchu (którego pierwsze ogniwo w ręku Boga jest pierwsza z wszystkich przyczyn), przeto działania te wypływaja z konieczności” (Hobbes 1954: 186). Pascal potępia libido dominandi, Hobbes i Bourdieu wychodzą od niego jako podstawowej rzeczywistości antropologicznej. Świat, w którym panuje wola mocy, zamienia się - jak pisze Bourdieu (1984) - w „zderzenie niewspółmiernych perspektyw”, „symboliczną walkę wszystkich ze wszystkimi”, we „wszechświat oskarżających i oskarżonych”, a także w ,rywalizację o władzę, którą można uzyskać jedynie od innych rywali walczących o tę samą władzę, władzę nad innymi ludźmi, która istnieje dzięki innym, dzięki ich spojrzeniu, dzięki ich postrzeganiu i ocenie (sprawia to, że nie trzeba wybierać między homo homini lupus Hobbesa a homo homini deus Spinozy)" (Bourdieu 2006: 344-345). Nawet gdy Bourdieu odchodzi od wizji Hobbesa, a uzupełnia ją o wizję Spinozy, w istocie cały czas pozostaje w jej orbicie. Hobbes bowiem zdawał sobie doskonale sprawę - co podkreśla Schmitt - że zasada homo homini lupus obowiązuje w stanie natury, a w stanie łaski, tzn. w państwie, dominuje logika homo bomini deus (Schmitt 2008: 42). Kiedy Schmitt głosi za Hobbesem, że każda forma rządu jest z konieczności absolutna, Bourdieu wypowiada dokładnie te same słowa. Schmitt dostrzega, że natura jest skażona i jedynie moc suwerena może nadać jej porządek, suweren w istocie tworzy człowieka, on nadaje mu łaskę i określa, jakie są dopuszczalne formy kultu i na czym polegaja cuda. Tak samo twierdzi Bourdieu (Bourdieu 2006: 344). Różnią ich tylko wnioski praktyczne. O ile Schmitt broni absolutnej przemocy suwerena, Bourdieu uznaje ja za przemoc symboliczną, którą należy ujawnić i przezwyciężyć. Schmitt głosi kult Państwa, które wygasza konflikty, a Bourdieu atakuje Państwo, ponieważ wygasiło ono już wszelki konflikt. Ani jeden, ani drugi nie wychodzi poza horyzont Państwa. Dla nich poza Państwem nie ma zbawienia. Schmitt staje po stronie Wielkiego Inkwizytora, który odsyła Chrystusa w zaświaty, a Bourdieu staje przeciwko Wielkiemu Inkwizytorowi, ale

\footnotetext{
${ }^{14}$ Carl Schmitt (2008: 42-43) zwraca uwagę, że mechanizm double bind obecny jest także u Hobbesa. Ponieważ angielski filozof broni się przeciw roszczeniom ortodoksów (papieża) i heretyków (purytan), którzy w równej mierze powołują się na Boga, „nie może po prostu zostawić boskości swoim przeciwnikom i kościołowi”: „Każdy okrada wroga, czy tego chce, czy nie”. Podobieństwo między Bourdieu a Hobbesem bierze się stąd, że - jak sugerowałem - łączy ich sprzeciw zarówno wobec religijnych ortodoksów, jak i heretyków.
} 
nie wzywa Chrystusa. Jeden z największych socjologów XX wieku, Bourdieu, stanowi przykład przedziwnego paradoksu, będąc w teorii teologiem antyteologii.

\section{/// Aneks. Kilka uwag o ruchu gnostyckim i nowoczesności}

Myśl Bourdieu jest interesującym przykładem głębokiego związku między nowoczesnością a gnostycyzmem ${ }^{15}$. Hans Blumenberg (Lazier 2013) i Odo Marquard $(2001,2004)$ definiują nowoczesność jako przezwyciężanie chrześcijańskiego monoteizmu i wiążącej się z nim gnozy. W konsekwencji następuje proces „odbierania złu znamion zła”. Przykład Bourdieu pokazuje, że właśnie z powodu przezwyciężenia chrześcijańskiego monoteizmu pojawia się gnoza. Nowoczesność nie przezwycięża gnozy, ale ja produkuje jako efekt uboczny. Wbrew temu, co sugeruje Lazier (2013) w swym komentarzu do Blumenberga i Jonasa, sekularyzacja, uświatowienie (Verweltlichung) Boga nie tylko nie jest sprzeczne, ale idzie w parze z impulsem gnostyckim i odświatowieniem Boga (Entweltlichung). Z jednej strony, Bóg zostaje zimmanentyzowany, przybierając formę Państwa, a z drugiej - Bóg oddala się, następuje zerwanie między nim a światem. W konsekwencji świat staje się żelazną skorupa, w której - być może - skryte są iskry pochodzące nie z tego świata. Ten gnostycki element możemy paradoksalnie odnaleźć także $\mathrm{u}$ antygnostyka Blumenberga w jego koncepcji ,absolutyzmu rzeczywistości”. Rzeczywistość zastępuje u niego Absolut, staje się ostateczną, niezniszczalną podstawą (zob. także Grad 2013).

Gnostycka wizja świata u Bourdieu nie była skutkiem filozoficznej medytacji, ale badań terenowych. Bourdieu stawał się gnostykiem dlatego, że gnostykami byli mieszkańcy Algierii, od których rozpoczął swoją konwersję socjologiczna. ,Życie codzienne - pisał - jest [dla nich] doświadczane jako rezultat rodzaju systemowego planu wyobrażonego przez jaką́s złą wolę. Kolonialny system postrzegany jest jako złośliwy i ukryty bóg, ucieleśniony w zależności od okazji i okoliczności przez Europejczyków, Hiszpanów, Francuzów, administrację, rząd, onych" (Bourdieu 2013: 89, 178). Zmiana widzenia świata była więc dla Bourdieu w istocie powrotem, anamnezą najwcześniejszych doświadczeń badawczych. Z tego punktu widzenia nie było żadnej zmiany, a jedynie powtórzenie.

15 Pomijam tutaj autorską interpretację gnozy, jaką sformułował Eric Voegelin (1992), która zbieżna jest z wizja Jonasa i Blumenberga jedynie w ocenie gnostycyzmu Hobbesa. 
Na głębszym poziomie - poziomie nie pojęć, metafor, lecz struktury narracji-Bourdieu powielał światopogląd swoich badanych. Jeśli w jego życiu nastapiła jakaś konwersja, to wiodła ona nie do gnozy, ale do aktywizmu społecznego. Otóż od końca lat 80. stawał się on coraz bardziej zaangażowanym socjologiem, walcząc $z$ neoliberalizmem, tyranią rynku i mediów (Lane 2006). Ta ewolucja wiązała się ze zmianą wizji państwa, które naraz zaczął opisywać zupełnie inaczej niż dotychczas. Nie tylko zaczął bronić „francuskiego modelu” i „francuskiej wyjątkowości”, lecz także wezwał do obrony „Heglowskiej i Durkheimowskiej wizji państwa” jako gwaranta uniwersalnych praw (Lane 2006: 4). W obliczu neoliberalizmu, który przejął rolę ,złego Boga”, naraz Państwo stało się punktem oparcia. Było to całkowicie sprzeczne (co uderzyło wielu komentatorów) z jego wcześniejszą krytyką Państwa i jego „myślicielifunkcjonariuszy": Hegla i Durkheima (dodajmy także Hobbesa), którzy ulegali „uwodzicielskim wyobrażeniom państwa” (Bourdieu 2009: 76, 78). Można by zaryzykować hipotezę, że w świetle swych rozważań z Duchów państwa Bourdieu sam stał się myślicielem-funkcjonariuszem i uległ sile państwowego deus deceptor. W ten sposób teologia polityczna Carla Schmitta odniosła zwycięstwo nad teologia polityczną Bourdieu. Schmitt (2008: 34-40) podziwiał Hobbesa, który sprawił, że Lewiatan z symbolu demonicznego stał się politycznym symbolem ładu społecznego. Na podobnej zasadzie Państwo, które było u Bourdieu synonimem zła, w końcu stało się dla niego ostatnią instancją.

Driekeuje za pomoc Tomaszowi Warczokowi, który wskazat mi kluczowe teologiczne konteksty myślenia Bourdieu, Robertowi Pawlikowi, Pawtowi Gradowi oraz. Tomaszowi Zaryckiemu, a takize trzem anonimowym recenzentom. Tekst (za który nota bene biore pelnq odpowiedzialnosí) zostat napisany w ramach środków DSM 107700 IS UW. 
Bibliografia:

/// Böckenförde E.W. 2005-2006. Teoria polityki a teologia polityczna. Uwagi na temat ich wrajemnego stosunku, tłum. M. Kurkowska, „Teologia Polityczna”, nr 3, s. 301-309.

/// Boudon R. 2003. Pour une sociologie critique, [w:] Y a-t-il encore une sociologie?, Odile Jacob, Paris, s. 123-159.

/// Bourdieu P., Wacquant L. 2001. Zaproszenie do socjologii refleksyjnej, tłum. A. Sawisz, Oficyna Naukowa, Warszawa.

/// Bourdieu P. 1984. La Dernière Instance, [w:] red. Y. David, J.-P. Morel, Le Siècle de Kafkea, Centre Georges Pompidou, Paris, s. 268-270.

/// Bourdieu P. 1986. Force of Law. Toward a Sociology of the Juridical Field, „Hastings Law Journal”, nr 38, s. 814-853.

/// Bourdieu P. 1988. Homo academicus, Stanford University Press, Stanford.

/// Bourdieu P. 1990. In other words. Essays towards a reflexive sociology, Stanford University Press, Stanford.

/// Bourdieu P. 1991. The political ontology of Martin Heidegger, Stanford University Press, Stanford.

/// Bourdieu P. 1993. Sociology in Question, Sage, London.

/// Bourdieu P. 1996. The State Nobility. Elite Schools in the Field of Power, Stanford University Press, Stanford.

/// Bourdieu P. 2001. Reguly sztuki. Geneza i struktura pola literackiego, tłum. A. Zawadzki, Universitas, Kraków.

/// Bourdieu P. 2004a. From the King's House to the Reason of State. A Model of the Genesis of the Bureaucratic Field, „Constellations”, nr 11, s. 16-36.

/// Bourdieu P. 2004b. Meskea dominacja, tłum. L. Kopciewicz, Oficyna Naukowa, Warszawa.

/// Bourdieu P. 2004c. Science of Science and Reflexivity, Polity, Cambridge.

/// Bourdieu P. 2006. Medytacje pascaliańskie, tłum. K. Wakar, Oficyna Naukowa, Warszawa. 
/// Bourdieu P. 2007. Sžkic teorii praktyki, popržedzony trzema studiami na temat etnologii Kabylów, tłum. W. Kroker, Wydawnictwo Antyk, Kęty.

/// Bourdieu, P. 2009. Rozum praktyczny. O teorii dziatania, tłum. J. Stryjczyk, WUJ, Kraków.

/// Bourdieu P. 2013. Algerian Sketches, Polity, Cambridge.

/// Bourdieu P. 2014. On the State, Polity, Cambridge.

/// Bourdieu P. 2015. O społecznej naturze symboli [posłowie do Architektury gotyckiej i scholastyki Erwina Panofskiego], „Stan Rzeczy” 2015, nr 8, s. $163-185$.

/// Bourdieu P., De Saint-Martin M. 1982. La Sainte Famille. L'Episcopat frangais dans le champ du pouvoir, „Actes de la recherche en sciences sociales", nr 44-45, s. 2-53.

/// Brod M. 1982. Franz Kafka. Opowieśś biograficzna, tłum. T. Zabłudowski, Czytelnik, Warszawa.

/// Budzik S. 1997. Dramat odkupienia. Kategorie dramatycrne w teologii na preyktadzie R. Girarda, H. U. von Balthasara i R. Schwagera, Biblos, Tarnów.

/// Carnevali B. 2013. Girard-Bourdieu. Les origines angustiniennes d'une affinité anthropologique, wystąpienie na konferencji Girard-Bourdieu. Des affinités méconnues, 18 czerwca 2013 roku.

/// Cassirer E. 2006. Mit państwa, tłum. A. Staniewska, Wydawnictwo IFiS PAN, Warszawa.

/// Descartes R. 1998. List do Voetiusa, tłum. J. Usakiewicz, Wydawnictwo Naukowe PWN, Warszawa.

/// Descartes R. 2001. Medytacje o pierwszej filozofii. Zarzuty uczonych mèzón i odpowiedzi autora. Rozmowa z Burmanem, tłum. M. i K. Ajdukiewiczowie i inni, Wydawnictwo Antyk, Kęty.

/// Dianteill E. 2003. Pierre Bourdieu and the Sociology of Religion. A Central and Peripheral Concern, „Theory and Society” 2003, nr 5-6, s. 529-549.

/// Domański J. 1997. Z dawnych rozważań o marności i pogardz̧e świata oraz. nedzy i godności çłowieka, Wydawnictwo IFiS PAN, Warszawa. 
/// Flahault F. 2013. Chers Jansénistes, un peu de sollicitude pour la difficulté d'exister, wystapienie na konferencji Girard-Bourdieu. Des affinités méconnues, 18 czerwca 2013 roku.

/// Flanagan K. 2007. Sociology in Theology. Reflexivity and Belief, Palgrave Macmillan, Basingstoke.

/// Gdula M. 2009. Trzy dyskursy mitosne, Oficyna Naukowa, Warszawa.

/// Gierycz M. 2007. Teologia polityczna a metoda badania relacji religii i polityki w procesie integracji europejskiej, „Przegląd Europejski”, nr 2, s. 39-50.

/// Girard R. 2006. Poczqtki kultury, tłum M. Romanek, Wydawnictwo Znak, Kraków.

/// Grad P. 2013. Osadzicić nowożytność. Wokót korespondencji Hansa Blumenberga i Carla Schmitta, „Kronos”, nr 2, s. 161-169.

/// Grözinger K.E. 2006. Kafka a Kabała. Pierwiastek \&̇ydowski w driele i myśleniu Franz̧a Kafki, tłum. J. Güntner, Austeria, Kraków.

/// Hałas E. 2013. Między odrzuceniem religii a z̧bawianiem świata. Itineraria socjologii i postsekularnej teorii społecznej, „Stan Rzeczy”, nr 5, s. 13-29.

/// Hobbes T. 1954. Lewiatan, czyli materia, forma i władza państwa kościelnego $i$ swieckiego, tłum. Cz. Znamierowski, Wydawnictwo Naukowe PWN, Warszawa.

/// Jonas H. 1994. Religia gnozy, tłum. M. Klimowicz, Wydawnictwo Platan, Kraków.

/// Jussen B. 2009. The King's Two Bodies Today, „Representations”, nr 108, s. 102-117.

/// Kantorowicz E.H. 2007. Dwa ciala króla. Studium ze średniowiecznej teologii politycznej, tłum. M. Michalski, A. Krawiec, Wydawnictwo Naukowe PWN, Warszawa.

/// Kantorowicz E.H. 2008. Kalendarium życia i twórczości (przygotował Robert Pawlik), „Kronos”, nr 4, s. 49-68.

/// Kołakowski L. 2001. Bóg nam nic nie jest dtużny. Krótka unaga o religii Pascala i o duchu janseniżmu, Wydawnictwo Znak, Kraków.

/// Koselleck R. 2001. Semantyka historyczna, tłum W. Kunicki, Wydawnictwo Poznańskie, Poznań. 
/// Lamont M. 1987. How to Become a Dominant French Philosopher. The Case of Jacques Derrida, „American Journal of Sociology”, nr 3, s. 584-622.

/// Lane J.F. 2006. Bourdieu's Politics. Problems and Possiblities, Routledge, London.

/// Lazier B. 2013. Przezanycieżý gnoze. Hans Jonas, Hans Blumenberg i prawomocność świata natury, tłum. R. Zawisza, „Kronos”, nr 2, s. 142-160.

/// Lipszyc A. 2012. Sprawiedliwość na końcu jezyka. Czytanie Waltera Benjamina, Universitas, Kraków .

/// Marquard O. 2001. Szczeście w nieszcześciu. Rozważania filozoficæne, tłum. K. Krzemieniowa, Oficyna Naukowa, Warszawa.

/// Marquard O. 1994. Od monomityczności do polimityczności, [w:] tegoż, Rozstanie z filozofia pierwszych zasad. Studia filozoficzne, tłum. K. Krzemieniowa, Oficyna Naukowa, Warszawa.

/// Metz J.B. 2000. Teologia polityczna, tłum. A. Mosurek, Wydawnictwo WAM, Kraków.

/// Panofsky E. 1997. Three Essays on Style, MIT, Cambridge.

/// Pascal B. 1989. Myśli, tłum. T. Żeleński, Instytut Wydawniczy PAX, Warszawa.

/// Pawlik R. 2008. Dwa ciała króla. Średniowiecz̨na metaforologia politycz̨na Ernsta H. Kantorowicza, „Kronos”, nr 4, s. 42-48.

/// Pawlik R. 2013. Od pracy pojecia do pracy metafory. O metaforologii Hansa Blumenberga, „Kronos”, nr 2, s. 113-124.

/// Peyrefitte A. 1981. The Trouble with France, Knopf, New York.

/// Rey T. 2007. Bourdieu on Religion. Imposing Faith and Legitimacy, Equinox, London.

/// Rudolph K. 1995. Gnoz̧a. Istota i historia późnoantycznej formacji religijnej, tłum. G. Sowiński, Nomos, Kraków.

/// Schmitt C. 2000. Teologia polityczna i inne pisma, tłum. M. Cichocki, Wydawnictwo Znak, Kraków-Warszawa.

/// Schmitt C. 2008. Lewiatan w teorii państwa Thomasa Hobbesa. Sens i niepowodzenie politycznego symbolu, tłum. M. Falkowski, Prószyński i S-ka, Warszawa. 
/// Schmitt C. 2014. Teologia polityczna II, tłum. B. Baran, Wydawnictwo Aletheia, Warszawa.

/// Scholem G. 1995. Redemption Through the Sin, [w:] tegoż, The Messianic Idea in Judaism and Other Essays on Jewish Spirituality, Schocken, New York, s. 78-141.

/// Scholem G. 2006. Żydzৃi i Niemcy. Eseje, listy, rozmowa, tłum. A. Lipszyc, Wydawnictwo Pogranicze, Sejny.

/// Sosnowska P. 2013. Teologia polityczna i nowożytność. Hans Blumenberg kontra Carl Schmitt, „Kronos”, nr 2, s. 170-183.

/// Taubes J. 2013a. Apokalipsa i polityka. Eseje mesjańskie, tłum. Piotr Graczyk i inni, Fundacja Augusta hr. Cieszkowskiego, Warszawa.

/// Taubes J. 2013b. Kafka, Kronos, nr 1, s. 206-207.

/// Verter B. 2003. Spiritual Capital. Theorizing Religion with Bourdieu against Bourdieu. „Sociological Theory”, nr 2, s. 150-174.

/// Voegelin E. 1992. Nowa nanka polityki, tłum. P. Śpiewak, Wydawnictwo Aletheia, Warszawa.

/// Wagner I. 2012. Geniusz czy biznesmen? Sprzeżenie karier drogq do sukcesu w nauce, „Stan Rzeczy”, nr 2, 12-76.

/// Warczok T. 2010. Ład konsekrowany, tad zdenaturalizowany. O socjologii religii Pierre'a Bourdieu, [w:] Religijność $i$ duchowość. Dawne i nowe formy, red. M. Libiszowska-Żółtkowska, S. Grotowska, Nomos, Kraków, s. $154-166$.

\section{/// Abstrakt}

Pierre Bourdieu jest teologiem, teologiem politycznym. Jednym z najważniejszych źródeł (choć ukrytym) myśli autora Reprodukciji jest klasyczne dzieło Ernsta Kantorowicza Dwa ciała króla. Studium ze średniowiecænej teologii politycznej. Konstruując jedną z najbardziej wpływowych teorii społecznych XX wieku, francuski badacz czerpie pełnymi garściami z religijnych metafor i pojęć. Stanowią one nie tyle retoryczny ornament, lecz także istotę jego myśli. Należy poważnie potraktować deklarację Bourdieu, że jest uczniem Pascala, „pascalianinem” (pascalien). Istnieje bowiem głęboka racja, że antyklerykał i ateista opowiada się za 
największym apologetą chrześcijaństwa. Otóż podziela on wizję Pascala z jednym ważnym zastrzeżeniem. Deus absconditus Pascala, który ma nas uwolnić od nędzy świata, zostaje zakwestionowany, a cechy Boga jako wszechmocnego stwórcy i prawodawcy przechodzą na Państwo i naukę. W ten sposób Państwo zaczyna przypominać demiurga, Boga zła. Ponieważ Bourdieu nie wierzy w religijne drogi emancypacji spod władzy Państwa, emancypacja jako taka staje pod znakiem zapytania. Francuski socjolog znajduje jednak dwie wysoce ryzykowne drogi wyjścia: wiedzę i miłość. Emancypacja rozpoczyna się od wycofania się ze świata - od zmiany samego siebie, która jest warunkiem wszystkich zmian. Przez pokorę i ascezę wiedzie droga do konwersji naukowej, poprzez praktyki antynomijne wiedzie droga miłości. Odpowiada to dwóm wersjom gnostycyzmu: ascetycznej i libertyńskiej. W końcu jednak sam Bourdieu ulega sile Państwa i paradoksalnie staje po stronie Carla Schmitta.

Słowa kluczowe:

teoria społeczna, teologia polityczna, Bourdieu, Kantorowicz, Kafka, Pascal

\section{/// Abstract}

Pierre Bourdieu is a theologian, a political theologian. One of the important, but hidden, source of his work is the classic work The King's Two Bodies: A Study in Mediaeval Political Theology. While constructing one of the most influential social theories of the $20^{\text {th }}$ century the French scholar draws handfuls of religious metaphors and concepts. These are not merely rhetorical ornaments; they are the essence of his thinking. We ought to treat seriously Bourdieu's declaration that he is a Pascalian. There is a profound reason why the anti-cleric and atheist declares himself in favor of the greatest Christian apologist. This is because he shares Pascal's vision with one important reservation. The Deus absconditus of Pascal, who is supposed to free us from the wretchedness of the world, is challenged while the qualities of God as the omnipotent creator and lawgiver are transferred to the State and science. In this way the State becomes reminiscent of the Gnostic demiurge, an evil God. Since Bourdieu does not believe in religious paths of emancipation from the power of the State, emancipation in itself become questionable. However, the French sociologist finds two risky ways out: knowledge and love. Emancipation begins with a withdrawal from the world, from changing oneself, which is the pre-condition for all changes. 
Humility and ascesis lead one along the path toward scientific conversion; the path of love leads through antinomic practices. This corresponds to two versions of Gnosticism: ascetic and libertine. In the end Bourdieu himself succumbed to the power of the State and paradoxically ended up on the same side as Carl Schmitt.

Keywords:

social theory, political theology, Bourdieu, Kantorowicz, Kafka, Pascal, Schmitt, Jonas 